\title{
The Development of Student Worksheets Based on Simulation Methods
}

\author{
Mispandi ${ }^{1}$, Endang Mulyani ${ }^{2}$ \\ ${ }^{1}$ Universitas Negeri Yogyakarta, Indonesia \\ ${ }_{2}^{2}$ Universitas Negeri Yogyakarta, Indonesia
}

\section{Article Info}

Article history:

Received: 11 September 2019;

Accepted: 24 February 2020;

Published: 1 March 2020.

Keywords:

Development; Student Worksheets; Simulation Methods; Student Learning Outcomes.

\begin{abstract}
This study aims to determine, the process of development, eligibility and student responses to student worksheets based on simulation methods. This type of research is Research and Development (R\&D), using the Borg $\&$ Gall development model. The subjects of the study were students of class XI of SMA Negeri 1 Sambelia. The results showed that the results obtained were validated material, language, and design 3.44 with the appropriate category, and the students' response was 4.16 with the appropriate category. The results showed that the development of student worksheets based on simulation methods was feasible to use and influenced student learning outcomes in economic subjects. The contribution of research as a tool in the learning process for teachers and students in schools.
\end{abstract}

\begin{abstract}
Abstrak
$\overline{\text { Penelitian ini bertujuan untuk mengetahui, proses pengembangan, kelayakan }}$ dan respon siswa terhadap lembar kerja siswa berbasis metode simulasi. Jenis penelitian ini adalah Penelitian dan Pengembangan (R\&D), menggunakan model pengembangan Borg \& Gall. Subjek penelitian adalah siswa kelas XI SMA Negeri 1 Sambelia. Hasil penelitian menunjukkan bahwa, hasil yang diperoleh adalah validasi materi, bahasa, dan desain 3,44 dengan kategori yang sesuai, dan respon siswa adalah 4,16 dengan kategori yang sesuai. Hasil penelitian menunjukkan bahwa pengembangan lembar kerja siswa berbasis metode simulasi layak untuk digunakan dan mempengaruhi hasil belajar siswa dalam mata pelajaran ekonomi. Kontribusi penelitian sebagai alat dalam proses pembelajaran bagi guru dan siswa di sekolah.
\end{abstract}

\section{How to Cite:}

Mispandi, M., \& Mulyani, E. (2020). The Development of Student Worksheets Based on Simulation Methods. Jurnal Pendidikan Ekonomi \& Bisnis, 8(1), 14-24. https://doi.org/10.21009/JPEB.008.1.2

\footnotetext{
* Corresponding Author.
} mispandi.2018@student.uny.ac.id. Mispandi 


\section{INTRODUCTION}

The development of science and technology greatly affects various aspects of life both from aspects of economic, political, social, and cultural facilities including education. Education is an important investment in producing human resources and one of the means to produce high-quality human resources and important factors in development in the era of globalization that places science and technology (Blaug, 1967; Oecd \& OECD, 2014; Psacharopoulos, 1970; Reece, 1978; Scott Norton, 2008; Shah \& Steinberg, 2019). Learning is a process given by the teacher to train students in the learning process and gain knowledge, skills, and attitudes (Cross, 2000; Litchfield \& Dempsey, 2015; "Literary Literacy and Intercultural Competence: Furthering Students' Knowledge, Skills and Attitudes," n.d.; Rhodes \& Burgess, 2018).

Learning outcomes are the abilities of students both cognitive, affective, or psychomotor obtained through the learning process used as a benchmark for the success of students (Tirangka, Maddatuang, \& Nyompa, 2017). in learning, activities must utilize technology and optimal potential environment so that learning is more meaningful, but in reality, it is not always done by the teacher (Georgette, n.d.; Misseyanni, Lytras, Papadopoulou, \& Marouli, 2018; Wolf \& Fraser, 2008). Various studies have shown that students at various levels of education in Indonesia still have low learning outcomes, this is due to the learning that is happening now tends to be contextual, and the potential of the local environment is underused by teachers in the learning process, whereas when combining learning culture can beneficial for all students (Allchin, 2014; Gondwe \& Longnecker, 2015; Liu, 2013). Empirical findings indicate that efforts to improve learning outcomes in education by using various learning methods and creating student worksheets such as Reciprocal Teaching (Bupu, Rukayah, \& Subiyantoro, 2018; Hendri \& Permatasari, 2019; Ningsyih, Andayani, \& Hakim, 2017; Nirwana, Nirwana, \& Rochman, 2018; Purnawan, 2018; Sugiharti \& Habeahan, 2018; Zaiyasni \& Zaiyasni, 2017).

Learning resources are materials that can be used to help teachers or students in the learning process, which can be in the form of textbooks, print media, electronic learning media, resource persons, the surrounding natural environment and others as learning experiences in accordance with the objectives to be achieved (Al-Khafaji \& Sriram, 2015; Dopo \& Ismaniati, 2016; Information technology. Learning, education, and training. Metadata for learning resources, n.d.; OECD, 2009). According to (Branch \& Fitzgerald, 1999; Jonassen \& Driscoll, 2003) learning resources are all things or resources that are used by teachers, both separately and in a combined form, for the benefit of teaching and learning with the aim of increasing the effectiveness and efficiency of learning objectives. in research (Trnova \& Trna, 2017) states that the teacher must create new modules and focus on student learning activities. Development of student worksheets can be used to improve student knowledge and learning outcomes and can be a reference material for students in discussing ideas related to learning (Hamdu \& Yulianto, 2018; Murni, Anggraini, \& Sakur, 2018; Nur'Afifah \& Man, 2018).

The above statement shows, that in addition to using the learning method approach that has been carried out in various studies, technology, and student worksheets can also be used as a supporting tool in learning so that the learning process can facilitate the learning process activities of students effectively, efficiently and enhance positive attitudes as well as student learning motivation towards learning both in the classroom and outside the classroom that leads to achieving optimal learning outcomes (Al-Harbi \& Alshumaimeri, 2016; Al-Kathiri, 2014; Purnawarman, Danuwijaya, \& Ningrum, 2017). However, in reality in the field, many teachers have not developed methods and student worksheets, so that student learning outcomes are still below the values set by the school and student motivation is lacking. therefore researchers provide solutions with the development of student worksheets based on simulation methods and their effects on learning results of class xi high school students in economic learning. this research contributes to provide a means in the learning process for teachers and students in schools.

The results of interviews with economics teachers at SMAN 1 Sambelia show that the use of Student Worksheets has not been used to the fullest, student worksheets are only a guide for students, as assignments, and student evaluation materials. Student Worksheets are still used conventionally. The teacher only explains the material contained in student worksheets without 
developing it using existing strategies, methods, or learning models. The teacher still plays an active role in the use of Student Work without including the student's role.

The survey results also showed that the use of conventional methods applied to learning, especially economic subjects that contain more material and numerical material, causes students to quickly feel bored to learn, students will also become passive in the learning process. This is less motivating students to learn and cause low student learning outcomes.

Conventional learning in economics basically still needs to be applied, but this learning is not appropriate if it is not modified with the learning method. For this reason, researchers try to develop student worksheets using simulation methods. This method helps students to foster creativity and understanding of the current economic situation by imitating the behavior process. This learning will create students who actively participate and work together because the learning process is played by at least two people.

Based on the background that has been described above, the researcher feels the need for the development of student worksheets to overcome existing problems and in general, the boundaries of the problems in this study are: (1) Developing student worksheets based on simulation methods, (2) Analyzing feasibility student worksheets based on simulation methods according to experts, (2) Analyze student responses to student worksheets based on simulation methods developed, (3) analyze student learning outcomes improvement through student worksheets based on simulation methods developed.

\section{METHOD}

This research is a type of Research and Development (R\&D). This development research is used to produce student worksheets based on simulation methods and their effects on the learning outcomes of class XI high school students in economic learning. The model used in this research development modifies the Borg and Gall development model (Sugiyono, 2015). The procedure in the research development of student worksheets with this simulation method is carried out through 7 (seven) stages, namely; research and information gathering, planning, developing preliminary forms of product, preliminary field testing, main product revision, operational field testing, final product revision.

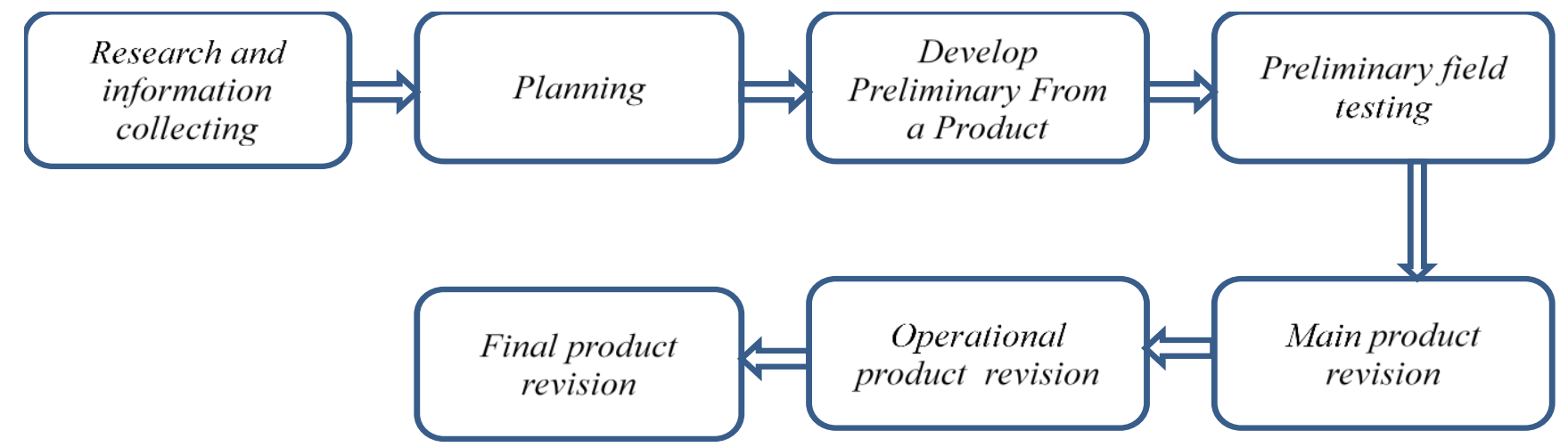

Figure 1. Development Research Model (Modified Borg and Gall theory, 2003)

Data collection methods in this research use, survey methods, interview methods, questionnaire instruments, and tests. As for the data analysis using t-test analysis and quantitative descriptive analysis. The t-test is basically to test the null hypothesis about the difference in mean of the two samples or two variables (Yatim Riyanto, 1996). In this study, researchers used the t-test for the same sample and the heterogeneous variance: 


$$
t=\frac{X_{1}+X_{2}}{\sqrt{\frac{S_{1}^{2}}{n_{1}}+\frac{s_{2}^{2}}{n_{2}}}}
$$

Information:

$\mathrm{X} 1=$ Sample mean 1

$\mathrm{X} 2=$ Sample mean 2

$\mathrm{S} 21=$ Sample variant 1

S22 = Sample variant 2

$\mathrm{N} \quad=$ number of cases for each sample

While quantitative descriptive analysis is used to process data obtained through a questionnaire in the form of a score, which aims to determine the feasibility of student worksheets developed. Following are the steps to analyze data from eligibility:

a. Turning qualitative data into quantitative data. Quantitative data on material expert assessment scores and student response questionnaires were analyzed descriptively by referencing the value conversion table as follows.

Table 1. Assessment Criteria Likert Scale Validation Questionnaire

\begin{tabular}{cc}
\hline Alternative Answer & Scores \\
\hline Very good & 5 \\
Good & 4 \\
Enough & 3 \\
Minus & 2 \\
Very less & 1 \\
\hline
\end{tabular}

Source: Learning Evaluation (Sukardjo, 2005)

b. Calculate the average value of each aspect using the formula Sukardjo (2005) as follows:

$\mathrm{X}=\left(\sum \mathrm{X}\right) / \mathrm{N}$

Information:

$\mathrm{X}=$ average score

$\sum \mathrm{X}=$ Number of scores

$\mathrm{N}=$ Number of test subjects

c. Change the average value into qualitative data using categories (Sukardjo, 2005: 25) as follows:

Table 2. Converting Quantitative Data (Validation Score) to Qualitative Data

\begin{tabular}{lclcc}
\hline No. & Category & Score & Score Interval & Range \\
\hline 1. & Very decent & $\mathrm{A}$ & $\overline{\mathrm{X}}>\mathrm{X}+1.80 \mathrm{Sbi}$ & $\mathrm{X}>4.20$ \\
2. & Feasible & $\mathrm{B}$ & $\mathrm{X}>0,60 \mathrm{SBi}<\mathrm{X}<\mathrm{X}+1.80 \mathrm{Sbi}$ & $3.40<\mathrm{X} \leq 4.20$ \\
3. & Enough & $\mathrm{C}$ & $\mathrm{X}-0,60 \mathrm{SBi}<\mathrm{X}<\mathrm{X}+1.80 \mathrm{Sbi}$ & $2,60<\mathrm{X} \leq 3.40$ \\
4. & Less & $\mathrm{D}$ & $\mathrm{X}-1,80 \mathrm{SBi}<\mathrm{X}<\mathrm{X}-1.80 \mathrm{Sbi}$ & $1.80<\mathrm{X} \leq 2.60$ \\
5. & Very Less & $\mathrm{E}$ & $\overline{\mathrm{X}}<\mathrm{X}-1,80 \mathrm{Sbi}$ & $\mathrm{X} \leq 1.80$ \\
\hline
\end{tabular}

Source: Learning Evaluation (Sukardjo, 2005)

Information:

$\mathrm{X}=$ Actual score (score obtained)

$\mathrm{X}=($ Average average $)$

$=1 / 2($ maximum score + minimum score $)$

$=1 / 2(5+1)$

$=3$

$$
\begin{aligned}
\text { Sbi } & =(\text { Ideal standard deviation }) \\
& =1 / 6(\text { maximum score-minimum score }) \\
& =1 / 6(5-1) \\
& =0.67
\end{aligned}
$$




\section{RESULTS AND DISCUSSION}

This research and development sheet design results in a product in the form of a student worksheet based on a simulation method. The research and development of this tool aims to obtain a learning device that is valid and suitable for use as a reference in learning activities. SMAN 1 Sambelia in general students of class XI IPS in 2018/2019 year are divided into 3 classes that have similar characteristics and there are no superior classes, which means that in each class there are students who are classified as high, medium, and classified as low-cognitive. Students who are the subjects of research are class XI IPS 1.

However, before the student worksheets that were developed were tested on students. First, the Economics Student Worksheet is validated by one Material Expert, one Language Expert, and one Design Expert. After being validated and said to be feasible by the experts, then student work can be tested on students. Material Expert Validation of Student Worksheets is carried out in relation to aspects of the appropriateness of the contents of the student worksheets that were developed.

Table 3. Recapitulation of Student Worksheets Validation Results by Material Experts

\begin{tabular}{lcc}
\hline \multicolumn{1}{c}{ Eligibility Aspect } & Score & Average \\
\hline A. Coverage of Material & 10 & 3.33 \\
B. Material Accuracy & 11 & 3.67 \\
C. Proficiency and Contextual & 11 & 3.67 \\
D. Supporting Presentation of Material & 29 & 3.62 \\
E. Completeness of Presentation & 19 & 3.80 \\
The Number & 80 & 18.09 \\
An average & & 3.62 \\
Category & & Worthy \\
\hline
\end{tabular}

Source: Processed Research Development Data

Based on table 3 regarding the results of quantitative data (validation scores) to qualitative data (value categories), it is known that the average score (X) of 3.62 lies in the range of $3.41<\mathrm{X} \leq$ 4.21 which means the student worksheets developed to get a value of "B" with the category "Eligible". The results of the validation by the material experts indicate that the student worksheets that were developed based on the assessment of the aspects of the appropriateness of the content are worth testing according to the comments and suggestions of the material experts.

Validation of Linguists on Student Worksheets is carried out in relation to the language feasibility aspects of the developed student worksheets. In addition to assessing the feasibility of language, linguists provide comments and suggestions to improve learning resources. In summary, the recapitulation of values is presented in the following table:

Table 4. Recapitulation of Validation Results for Student Worksheets by Linguists

\begin{tabular}{lcc}
\hline \multicolumn{1}{c}{ Eligibility Aspect } & Score & Average \\
\hline A. Conformity with the Development of Students & 6 & 3.00 \\
B. Readability & 3 & 3.00 \\
C. Ability to Motivate & 9 & 3.00 \\
D. Suitability & 8 & 4.00 \\
E. Flow-Flow Thinking & 8 & 4.00 \\
F. Compliance with KBI & 6 & 3.00 \\
G. Use of Terms and Symbols & 11 & 3.67 \\
The Number & 51 & 23.67 \\
An average & & 3.38 \\
Category & & Enough \\
\hline
\end{tabular}

Source: Processed Research Development Data

Based on table 4 regarding the results of quantitative data (validation scores) to qualitative data (value categories), it is known that the average score (X) of 3.38 lies in the range of $2.61<\mathrm{X} \leq$ 
3.40 which means the student worksheets developed to get a "C" in the "Fair" category. The results of the validation by linguists indicate that the student worksheets that were developed based on the assessment of aspects of language worthiness are worth testing according to the comments and suggestions of linguists.

The Design Expert Validation of the Student Worksheet was carried out related to the design feasibility aspects of the developed student worksheet that was carried out related to the design feasibility aspect of the student worksheet that was developed. In addition to assessing the feasibility of the design, design experts provide comments and suggestions to improve learning resources. In summary, the recapitulation of values is presented in the following table:

Table 5. Recapitulation of Student Worksheet Validation Results by Design Experts

\begin{tabular}{lcc}
\hline \multicolumn{1}{c}{ Eligibility Aspect } & Score & Average \\
\hline A. Book Size & 6 & 3.00 \\
B. Book Leather Design & 34 & 3.09 \\
C. Book Content Design & 27 & 3.86 \\
The Number & 67 & 9.95 \\
Average & & 3.32 \\
Category & & Enough \\
\hline
\end{tabular}

Source: Processed Research Development Data

Based on table 5 regarding the results of quantitative data (validation scores) to qualitative data (value categories), it is known that the average score $(\mathrm{X})$ of 3.32 lies in the range of $2.61<\mathrm{X} \leq$ 3.40 which means the student worksheets developed to get a "C" in the "Fair" category. The results of the validation by the design expert showed that the student worksheets that were developed based on an assessment of the feasibility aspects, were worth testing according to the comments and suggestions of the design experts. Based on the results of the validation of each validator against the student worksheets, an overall assessment of the media obtained in the following table:

Table 6. Comparison of Student Worksheet Validation Results by Experts

\begin{tabular}{|c|c|c|c|c|c|c|}
\hline \multirow[t]{2}{*}{ Eligibility Aspect } & \multicolumn{3}{|c|}{ Validator } & \multirow[t]{2}{*}{ Average } & \multirow[t]{2}{*}{ Value } & \multirow[t]{2}{*}{ Category } \\
\hline & $\begin{array}{c}\text { Material } \\
\text { Expert }\end{array}$ & Linguist & $\begin{array}{l}\text { Design } \\
\text { Expert }\end{array}$ & & & \\
\hline 1. Content & 18.09 & - & - & 3.62 & B & Worthy \\
\hline 2. Language & - & 23.67 & - & 3.38 & $\mathrm{C}$ & Enough \\
\hline 3. Design & - & - & 9.95 & 3.32 & $\mathrm{C}$ & Enough \\
\hline Average Overall Sco & & & & 3.44 & B & Worthy \\
\hline
\end{tabular}

Source: Processed Research Development Data

Table 6 shows that the average score of the aspect of content eligibility was ranked highest at 3.62. Then the second rank was obtained in the aspect of language eligibility with an average score of 3.38, and third was obtained in the aspect of design feasibility namely 3.32 and. The average overall score $(\mathrm{X})$ is 3.44 which lies in the range $3.41<\mathrm{X} \leq 4.21$ which is Decent. In conclusion, student worksheets get a "B" grade in the "Eligible" category.

After the product has been validated by experts, the design of learning resources that have been developed is applied to the actual conditions. Student worksheets will be trialed to students on trial subjects after the student worksheets are validated by the validator and through the revision stage. A trial was conducted to determine student responses and student learning outcomes towards learning resources, namely student worksheets that had been developed. Based on the trial results, the recapitulation is obtained as follows (table 7).

After the feasibility of the student worksheet is known, the researcher measures the increase in student learning outcomes that have been achieved. Data on increasing student learning outcomes were obtained after researchers conducted trials on 23 students of class XI IPS 1 of SMAN 1 Sambelia. Early student learning outcomes are obtained from even semester learning outcomes 
before the use of student worksheets with simulation methods. Then the final learning outcomes are obtained from learning outcomes after using student worksheets with simulation methods. Student learning outcomes before and after using student worksheets with simulation methods are then compared so that it can be seen the effect of student worksheets on learning outcomes in economic subjects. Classroom learning is conducted twice face-to-face with International Trade material, each time face-to-face is allocated as much as 2 hours of learning and each time of learning is 45 minutes.

Table 7. Recapitulation of Student Worksheet Validation Results by Trial Students

\begin{tabular}{llcccc}
\hline Eligibility Aspect & $\begin{array}{c}\text { The Number } \\
\text { Score }\end{array}$ & $\begin{array}{c}\text { Average } \\
\text { Score }\end{array}$ & Value & Category \\
\hline 1. Material & 101,43 & 4.41 & $\mathrm{~A}$ & Very decent \\
\hline 2. & Language & 91.33 & 3.97 & $\mathrm{~B}$ & Worthy \\
\hline 3. Design & 92.21 & 4.09 & $\mathrm{~B}$ & Worthy \\
\hline The Number & 284.97 & 12.47 & - & - \\
\hline Average & & 4.16 & $\mathrm{~B}$ & Worthy \\
\hline
\end{tabular}

After doing face-to-face learning, at the third meeting evaluation is conducted by giving students a test, the test questions consist of 10 indicators of cognitive ability. Then the final learning outcomes are obtained from the learning outcomes after the researcher finishes two meetings using student worksheets with the simulation method. Student learning outcomes before and after the use of student worksheets are compared so that an increase in learning outcomes can be known. The data is managed using SPSS version 16 to find out the results of descriptive statistics, the following are the results of the data that has been managed:

Table 8. Results of Descriptive Statistics Data Processing

\begin{tabular}{lcrrc}
\hline Information & Mean & $\mathrm{N}$ & Std. Deviation & Std. Error Mean \\
\hline Before & 77.8261 & 23 & 3.45953 & 0.72136 \\
\hline After & 82.1739 & 23 & 15.10163 & 3.14891 \\
\hline
\end{tabular}

Source: Processed Research Development Data

The results of data processing in table 8 show the results of calculating the average score (Mean) has increased from an average score before 77.82 to 82.17. The paired differences table shows that $(p)=0.01 \leq 0.05$. That is the influence before and after the use of student worksheets with simulation methods. Based on the results of data processing using SPSS version 16, the following is a recapitulation of the grades of students of class XI IPS 1 before and after using LKS with the simulation method:

Table 9. Student Learning Outcomes Before Using Student Worksheets

\begin{tabular}{ccccc}
\hline No & Interval & $\begin{array}{c}\text { The number } \\
\text { of students }\end{array}$ & Predicate & Category \\
\hline 1 & $90-100$ & - & $\mathrm{A}$ & Very Good \\
2 & $80-89$ & 10 & $\mathrm{~B}$ & Good \\
3 & $70-79$ & 13 & $\mathrm{C}$ & Enough \\
4 & $50-69$ & - & $\mathrm{D}$ & Less \\
\multicolumn{2}{c}{ The Number } & 23 & &
\end{tabular}

Source: Processed Research Development Data

Table 9 shows the learning outcomes before using student worksheets with the simulation method. The results obtained by students in the table above show that 13 students received grades at intervals of 70-79 namely the category "Enough", and 10 students got grades at intervals of 8089 namely the "Good" category. On the results of data processing using SPSS, the mean (Mean) 
obtained was 77,82 .

Table 10 shows the learning outcomes after using student worksheets with the simulation method. The results obtained by students in the table above show that 5 students get grades at intervals of 50-69 namely the "Less" category, 10 students get grades at intervals of 70-79 namely the category "Enough", 2 students get grades at intervals of 80-89 namely the category "Good", and 13 students got grades at intervals of 90-100 which is the "Very Good" category. In the results of data processing using SPSS, the mean (Mean) has increased from the average score of 82.17 with the category "Good".

Table 10. Student Learning Outcomes After Using Student Worksheets

\begin{tabular}{ccccc}
\hline No & Interval & $\begin{array}{c}\text { The number } \\
\text { of students }\end{array}$ & Predicate & Category \\
\hline 1 & $90-100$ & 13 & $\mathrm{~A}$ & Very Good \\
2 & $80-89$ & 2 & $\mathrm{~B}$ & Good \\
3 & $70-79$ & 3 & $\mathrm{C}$ & Enough \\
4 & $50-69$ & 5 & $\mathrm{D}$ & Less \\
\multicolumn{2}{c}{ The Number } & 23 & & \\
\hline
\end{tabular}

Source: Processed Research Development Data

The hypothesis proposed in this research trial consists of an alternative hypothesis (Ha), namely the development of student worksheets with the simulation method as a source of learning can improve student learning outcomes in economic subjects, and the null hypothesis (H0), namely the development of student worksheets with the simulation method as learning resources cannot improve student learning outcomes in economic subjects. To test this hypothesis, researchers used a paired sample t-test (paired-sample t-test). The following are the results of the t-test using SPSS version 16 :

Table 11. Correlation Test Results t

\begin{tabular}{ccccccc}
\hline Information & Mean & $\begin{array}{c}\text { Std. } \\
\text { Deviation }\end{array}$ & $\begin{array}{c}\text { Std. Error } \\
\text { Mean }\end{array}$ & t & df & $\begin{array}{c}\text { Sig. }(2- \\
\text { tailed }\end{array}$ \\
\hline Before After & -4.34783 & 15.04420 & 3.13693 & 2.386 & 22 & .018
\end{tabular}

Source: Processed Research Development Data

In the t-test, the t-count was 2.386. Whereas the t table calculation was obtained for 2.073 with $\mathrm{df} 22$. Because the $\mathrm{t}$-count $\geq \mathrm{t}$ table $(2.386 \geq 2.073)$ showed that $\mathrm{H} 0$ was rejected and Ha was accepted. This shows the development of student worksheets with the simulation method as a learning resource has a positive effect on student learning outcomes in economic learning. This is in accordance with Mu'tadin (2002) which states expressly one way to make students active and independent in learning is to use student worksheets so that the attitude of individual independence can be obtained cumulatively during development, where individuals will continue to learn independently in the face of various situations in the environment, so individuals are able to think and act on their own. This is also in accordance with the results of research by Handayani, A. (2013) that student worksheets have a positive effect on student learning outcomes in class XI IPS of SMA Negeri I Mojolaban in the academic year 2012/2013, by making a relative contribution of $62.5 \%$ and an effective contribution of $22,2 \%$. Then it can be concluded that the better the independence of student learning, the higher the economic learning outcomes obtained by students. Conversely, if the worse the independence of student learning, the lower the student's economic learning outcomes. 


\section{CONCLUSIONS AND SUGGESTION}

Based on the research results of the development of student worksheets based on simulation methods it can be concluded that; The feasibility level of student worksheets is known based on the assessment of several experts, that is, the assessment of eligibility by material experts obtained an average score of 3.62 included in the Eligible category. The feasibility assessment by linguists obtained an average score of 3.38 which belongs to the Fair category. The feasibility assessment by the design experts obtained an average score of 3.32 included in the Fair category. The response of IPS class XI students with the worksheets of students on the aspects of material eligibility of 4.41, a language of 3.97, and design of 4.09 showed an average score of 4.16 included in the Eligible category. Paired sample t-test results (paired-sample t-test) that have been processed from the results of student learning values obtained t-count of 2386 and t-table of 2.073 or t-arithmetic $\geq \mathrm{t}$ table $(2.338 \geq 2.073)$, these results indicate that $\mathrm{HO}$ is rejected, which means the development of student worksheets based on simulation methods as a learning resource can improve student economic learning outcomes.

\section{REFERENCES}

Al-Harbi, S. S., \& Alshumaimeri, Y. A. (2016). The Flipped Classroom Impact in Grammar Class on EFL Saudi Secondary School Students' Performances and Attitudes. English Language Teaching, Vol. 9, p. 60.

Al-Kathiri, F. (2014). Beyond the Classroom Walls: Edmodo in Saudi Secondary School EFL Instruction, Attitudes and Challenges. English Language Teaching, Vol. 8.

Alkhafaji, Salah \& B, Sriram. (2015). "Using Online Learning Resources: A Self Learning Tool". 10.14236/ewic/bcsme2014.15.

Allchin, D. (2014). From Science Studies to Scientific Literacy: A View from the Classroom. Science \& Education, Vol. 23, pp. 1911-1932.

Blaug, M. (1967). The Private and the Social Returns on Investment in Education: Some Results for Great Britain. The Journal of Human Resources, Vol. 2, p. 330.

Branch, R. M., \& Fitzgerald, M. A. (1999). Educational Media and Technology Yearbook 1999. Libraries Unlimited.

Bupu, S., Rukayah, R., \& Subiyantoro, S. (2018). Influence of Writing Poetry Module Using in Contextual Learning to Writing Poetry Learning Result of Elementary Student. International Journal of Multicultural and Multireligious Understanding, Vol. 5, p. 9.

Cross, R. (2000). Introduction: Strategic Learning in a Knowledge Economy: Individual, Collective and Organizational Learning Process. Strategic Learning in a Knowledge Economy, pp. vii - xviii.

dopo, F. B., \& Ismaniati, C. (2016). Persepsi Guru Tentang Digital Natives, Sumber Belajar Digital Dan Motivasi Memanfaatkan Sumber Belajar Digital. Jurnal Inovasi Teknologi Pendidikan, Vol. 3, p. 13.

Georgette, J. P. (n.d.). Active Learning using Model-Eliciting Activities and Inquiry-Based Learning Activities in Dynamics.

Gondwe, M., \& Longnecker, N. (2015). Scientific and Cultural Knowledge in Intercultural Science Education: Student Perceptions of Common Ground. Research in Science Education, Vol. 45, pp. 117-147.

Hamdu, G., \& Yulianto, A. (2018). The Ability of Prospective Preservice Elementary School Teachers to Develop Student Worksheets on Context-Based Science Learning. Mimbar Sekolah Dasar, Vol. 5, p. 155.

Handayani, A. (2013). Pengaruh Kemanfaatan Lembar Kerja Siswa (LKS) Dan Kemandirian Belajar Terhadap Hasil Belajar Siswa Ada Mata Pelajaran Ekonomi Kelas XI IPS SMA Negeri 1 Mojolaban Tahun Ajaran 2012/2013 (Doctoral dissertation, Universitas Muhammadiyah Surakarta).

Hendri, W., \& Permatasari, D. (2019). Relations EQ (Emotional Quotient) with Learning Result 
Bung Hatta University Biology Education Student. KnE Social Sciences, Vol. 3, p. 578.

Jonassen, D., \& Driscoll, M. (2003). Handbook of Research for Educational Communications and Technology: A Project of the Association for Educational Communications and Technology. Routledge.

Litchfield, B. C., \& Dempsey, J. V. (2015). Authentic Assessment of Knowledge, Skills, and Attitudes. New Directions for Teaching and Learning, Vol. 2015, pp. 65-80.

Literary Literacy and Intercultural Competence: Furthering Students' Knowledge, Skills and Attitudes. (n.d.). Learning with Literature in the EFL Classroom.

Liu, X. (2013). Expanding Notions of Scientific Literacy: A Reconceptualization of Aims of Science Education in the Knowledge Society. Science Education for Diversity, pp. 23-39.

Mannix, D. (1989). Be a Better Student: Lessons and Worksheets for Teaching Behavior Management in Grades 4-9. Prentice Hall Direct.

Misseyanni, A., Lytras, M. D., Papadopoulou, P., \& Marouli, C. (2018). Active Learning Strategies in Higher Education: Teaching for Leadership, Innovation, and Creativity. Emerald Group Publishing.

Murni, A., Anggraini, R. D., \& Sakur. (2018). The development of student worksheets based on metacognitive approach to improve students' mathematical representation ability. Journal of Physics: Conference Series, Vol. 1088, p. 012120.

Mu'tadin, Z. (2002). Kemandirian sebagai kebutuhan psikologis pada remaja. Jakarta:(http://www. e. psikologi. com/remaja/141508. htm). Diunduh tanggal, 27 November 2019.

Ningsyih, S., Andayani, Y., \& Hakim, A. (2017). Model Problem-based Student Worksheet Development, in Chemistry Learning. 2nd Asian Education Symposium.

Nirwana, Nirwana, \& Rochman, S. (2018). Implementation of problem based learning models in history of physics courses to promoting student learning result. Journal of Physics: Conference Series, Vol. 1116, p. 032025.

Nur'Afifah, R., \& Man, S. (2018). Design of Student Worksheets based on Learning Cycle 5E Learning Model for VIII Junior High School Students in Indonesia. International Journal of Engineering \& Technology, Vol. 7, p. 16.

OECD. (2009). Educational Research and Innovation Beyond Textbooks Digital Learning Resources as Systemic Innovation in the Nordic Countries: Digital Learning Resources as Systemic Innovation in the Nordic Countries. OECD Publishing.

Oecd, \& OECD. (2014). Education at a glance: ISCED-97, Financial and human resources investment in education (Edition 2014). OECD Education Statistics.

Psacharopoulos, G. (1970). Estimating Shadow Rates of Return to Investment in Education. The Journal of Human Resources, Vol. 5, p. 34.

Purnawan, R. A. (2018). Increasing Biology Learning Result With Cooperative Learning Type Student Teams Achievement Division (STAD). Biosfer, Vol. 7, pp. 58-63.

Purnawarman, P., Danuwijaya, A. A., \& Ningrum, A. R. (2017). High school students' perceptions of the application of Edmodo to English language learning. Ideas for 21st Century Education, pp. 351-357.

Reece, W. S. (1978). The Consumption and Investment Aspects of the Demand for Education: Comment. The Journal of Human Resources, Vol. 13, p. 429.

Rhodes, B., \& Burgess, A. (2018). An Innovative Educational Intervention to Improve Nursing Students' Knowledge, Attitudes, and Skills Surrounding Breastfeeding. Teaching and Learning in Nursing, Vol. 13, pp. 197-201.

Rizka, W., \& Lazulva, L. (2017). DESAIN DAN UJI COBA LEMBAR KERJA SISWA DENGAN PENDEKATAN SCAFFOLDING. Konfigurasi : Jurnal Pendidikan Kimia Dan Terapan, Vol. 1, p. 49.

Scott Norton, M. (2008). Human Resources Administration for Educational Leaders. SAGE. 
Shah, M., \& Steinberg, B. M. (2019). Workfare and Human Capital Investment: Evidence from India. Journal of Human Resources, pp. 1117-9201R2.

Sugiharti, G., \& Habeahan, B. J. W. (2018). Influence of Learning Model Using Laboratory and Numeric Ability to Student Learning Result on Thermochemical Material. International Education Studies, Vol. 11, p. 154.

Tirangka, M., Maddatuang, M., \& Nyompa, S. (2017). Motivation Improvement and Geography Learning Results Through Inquiry Based Learning Model to Class X-A Students at SMA Frater Makassar. UNM Geographic Journal, Vol. 1, p. 8.

Trnova, E., \& Trna, J. (2017). TEACHER CREATIVITY INFLUENCE ON THE TRAINING IN INQUIRY-BASED SCIENCE EDUCATION. INTED2017 Proceedings.

Wolf, S. J., \& Fraser, B. J. (2008). Learning Environment, Attitudes and Achievement among Middle-school Science Students Using Inquiry-based Laboratory Activities. Research in Science Education, Vol. 38, pp. 321-341.

Zaiyasni, D., \& Zaiyasni. (2017). Increasing Learning Result of Student IV Students Using Constructiveness Approach. Proceedings of the 9th International Conference for Science Educators and Teachers (ICSET 2017). 